\title{
Modern individual mobility
}

\author{
Hans-Jörg Althaus
}

Received: 30 November 2011 / Accepted: 30 November 2011 /Published online: 16 December 2011

(C) The Author(s) 2011. This article is published with open access at Springerlink.com

The transport sector is responsible for almost $60 \%$ of the oil consumption or almost $30 \%$ of the total energy consumption in OECD countries ${ }^{1}$ (IEA 2011). The dominant share of this energy consumption is caused by individual passenger transport by roads and air transport. Even though technological progress has constantly improved the fuel efficiency of vehicles combustion engines, the energy consumption of individual road transports is constantly increasing, mainly due to increasing population and increasing distances travelled daily. This leads to an increase in $\mathrm{CO}_{2}$ emissions from road transport in the EU by $20 \%$ between 1990 and 2000 (de Haan et al. 2007). Thus, individual mobility is one of the most relevant and fastest growing contributors to climate change. Also, human-toxic emissions from this sector are not negligible despite increasingly rigorous emission standards. The daily limit values for PM10 and for $\mathrm{NO}_{2}$ in 2009 still exceeded at more than $30 \%$ of the traffic sites across Europe (EU-27) ${ }^{2}$ and (Kunzli et al. 2000) attributed about $3 \%$ of total mortality in Austria, France and Switzerland to air pollution of motorized road traffic. And also external costs from road passenger transport in the USA due to air pollution are estimated higher than those due to climate change (Delucchi and McCubbin 2011).

\footnotetext{
${ }^{1} \mathrm{http}: / /$ www.iea.org/subjectqueries/keyresult.asp?KEYWORD_ $\mathrm{ID}=4121$, accessed 01.11.2011

${ }^{2} \mathrm{http} / / /$ www.eea.europa.eu/pressroom/newsreleases/european-transportsector-must-be, accessed 15.11.2011
}

\section{H.-J. Althaus ( $\square)$}

Empa, Swiss Federal Laboratories for Materials Science and

Technology, Technology and Society Laboratory,

Überlandstrasse 129 ,

8600 Dübendorf, Switzerland

e-mail: hans-joerg.althaus@empa.ch
From a global perspective, the transport sector is not only a very relevant but also a rapidly growing energy consumer: its share on worldwide primary energy consumption is expected to rise from $21.8 \%$ in 2000 to about $34 \%$ in 2050 (de Haan et al. 2007). Knowing that vehicle density per capita increases with increasing GDP (almost linear rise from 0 vehicles per capita at GDP 0 to 0.3 vehicles per capita at GDP $\$ 10,000$ ) and considering that annual economic growth in emerging nations like India (population 1.2 billion, GDP per capita about $\$ 3,500$, average annual growth ca. $7 \%)^{3}$ and China (population 1.3 billion, GDP per capita $\$ 7600$, average annual growth rate ca. $10 \%)^{4}$ is considerable, a steep increase in vehicle numbers and kilometers driven is to be expected. By 2050 one expects 5 billion cars (2010: 1 billion) driving 50 trillion $\mathrm{km}$ per year, emitting 6 billion tons of $\mathrm{CO}_{2}$ (i.e. about $20 \%$ of overall annual emission in 2010).

From this context, it is obvious that individual mobility is one of the most relevant issues in the discussions on climate change and urban pollution. Some years ago, biofuels were hoped to be the magic bullet to solve all problems. LCA, however, showed that even though many biofuels might have climate change mitigation potential, overall environmental effects of biofuel based mobility are often worse than for fossil fueled transports. And, just recently, the Scientific Committee of the European Environment Agency acknowledged a "serious error" in the greenhouse gas accounting methodology used for European Union regulations and policy targets. ${ }^{5}$

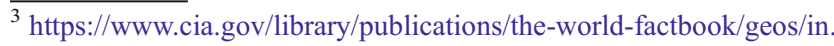
$\mathrm{html}$, accessed 01.11.2011

${ }^{4} \mathrm{https} / / /$ www.cia.gov/library/publications/the-world-factbook/geos/ch. html, accessed 01.11.2011

${ }^{5} \mathrm{http} / /$ www.eea.europa.eu/about-us/governance/scientific-committee/ sc-opinions/opinions-on-scientific-issues/sc-opinion-on-greenhouse-gas, accessed 15.11.2011
} 
Thus, even the climate change mitigation effect of biofuels is only true, if "land and plants are managed to take up additional $\mathrm{CO}_{2}$ beyond what they would absorb without conversion into bioenergy". 5 Another drawback of biofuels was found to be food competition.

But a new panacea is already at hand: electric mobility, based on batteries or on hydrogen. Obviously, critics are pointing their fingers at electricity generation which globally is based to two-thirds on coal, natural gas and oil (IEA 2011). Fossil electricity is produced at an energy efficiency of about 40\% (Graus et al. 2007), and a modern battery electric vehicle reaches plug to wheel energy efficiency of more than $75 \%$. The resulting energy efficiency is thus just above $30 \%-\mathrm{a}$ value only slightly higher than that of the most efficient commercially available diesel cars (e.g. Golf VI 1.6 TDi BM: $29 \%$ in the New European Drive Cycle (NEDC)). This rough estimate suggests that the potential of electric vehicles to mitigate environmental burdens cannot be huge as long as the electricity to drive these vehicles is not generated in a more environmentally friendly way than today's average generation. But the environmental burdens directly related to the energy consumption and its generation can be lower for electric vehicles if environmentally friendly electricity generation is considered for charging.

The critics go on and warn against overcompensation of potential benefits from a more environmental friendly use phase of electric vehicles by the production and disposal of batteries, electronic components, motors or fuel cells with their rare elements and exotic materials.

Several carbon-footprint, Well-to-Wheel or LCA studies were made to prove this fear right or wrong, and diverging results were produced. Only few very basic points seem to be generally accepted today:

- Vehicle mass-be it for electric or thermal vehiclesneeds to be minimized. This minimizes environmental burdens of the vehicle's production, and also, and more importantly, it minimizes the energy consumption in the use phase of the vehicle.

- If electricity generation is not environmental friendly, electric cars are not better (they can even be more burdensome) than clean and efficient diesel or natural gas fueled cars.

- Advantages of electric vehicles over vehicles with thermal engines are higher (or disadvantages lower) in places like inner cities, where local air pollution and engine noise are more relevant. (Engine noise of passenger cars is relevant at speeds below $40-50 \mathrm{~km} / \mathrm{h}$, while tire and aerodynamic noise is dominant at higher speed.)

This obviously is a rather weak consensus. And just because the issue is not complicated enough, there are not only thermal versus electric vehicles but there are also hybrids of all kinds: serial, parallel and mixed hybrids, plug-in-hybrids, hybrids with various thermal drivetrains (from internal combustion of diesel, petrol or gas to fuel cells).

The good news in this is that there is plenty of room for highly relevant LCA work in modern individual mobility. Case studies on various technological options can be made, vehicle concepts can be compared or simulations of potential developments of environmental impacts of individual mobility as a whole can be performed and analyzed. But also interesting methodological issues can be identified by looking at potential reasons for the variation of the results in the existing studies:

- Vehicle and component production: Primary industry data for most production processes of important components of (electric) vehicles like batteries, motors, electronic components etc. are rarely or not at all publicly available. Thus, these processes must either be theoretically modeled bottom-up, using methods or tools for process designing (e.g. Notter et al. 2010), or they are estimated top-down from sector or company generic indicators, often applying economic allocation (e.g. Zackrisson et al. 2010). What is the influence on the results? How can the quality of the data be assessed? How can data quality be improved?

- Fuel/energy consumption in vehicle's use phase: Consumption can be determined for standard drive cycles (e.g. NEDC) or for real world operation in average or specific (e.g. urban driving) situations. How should consumption values be determined? What is the influence on comparative results if vehicles of different technologies are compared applying different methods of determination of the consumption?

- Data and modeling of vehicle's end-of-life: Since recycling is very widespread with vehicles, allocation procedures for reuse and recycling might have an important impact on the results of transport or mobility studies. How large is the difference? Can the choice of allocation procedures influence comparative results for different technologies?

- Influence of background data: Most studies use generic data for the basic material and fuel production and for energy generation. Results can significantly differ for different sources, be it due to different system boundaries or cut-off criteria applied or due to different technologies. Are there systematic differences from the application of different background databases? How does the choice of a background database influence comparative results for different technologies?

- Impacts assessed: The choice of impact assessment methods can determine the ranking of technologies in comparisons. Most studies look at potential climate change impacts. Acidification, eutrophication and 
photochemical oxidation are also often reported. Many studies also use one or another end-point indicator like eco-indicator $99, \mathrm{ReCiPe}$ or ecological scarcity points. What assessment methods are relevant for what technologies or technology comparisons?

This list of topics is far from being comprehensive. We would like to invite practitioners and method developers to submit articles within the area of individual mobility in LCA, contributing to more adequate models and/or improved LCI data. We thus hope to achieve an improved understanding of environmental aspects and potential mitigation strategies in this highly relevant sector.

Open Access This article is distributed under the terms of the Creative Commons Attribution Noncommercial License which permits any noncommercial use, distribution, and reproduction in any medium, provided the original author(s) and source are credited.

\section{References}

de Haan P, Peters A, Scholz RW (2007) Reducing energy consumption in road transport through hybrid vehicles: investigation of rebound effects, and possible effects of tax rebates. J Clean Prod 15(11-12):1076-1084

Delucchi M, McCubbin D (2011) External costs of transport in the U. S. In: Palma AD, Lindsey R, Quinet E, Vickerman R (eds) A handbook of transport economics. Edward Elgar, Cheltenham

Graus WHJ, Voogt M, Worrell E (2007) International comparison of energy efficiency of fossil power generation. Energ Policy 35(7):3936-3951

IEA (2011) Key world energy statistics

Kunzli N, Kaiser R, Medina S, Studnicka M, Chanel O, Filliger P, Herry M, Horak F, Puybonnieux-Texier V, Quenel P, Schneider J, Seethaler R, Vergnaud JC, Sommer H (2000) Public-health impact of outdoor and traffic-related air pollution: a European assessment. Lancet 356(9232):795-801

Notter DA, Gauch M, Widmer R, Wager P, Stamp A, Zah R, Althaus H-J (2010) Contribution of li-ion batteries to the environmental impact of electric vehicles. Environ Sci Technol 44(17):6550-6556

Zackrisson M, Avellán L, Orlenius J (2010) Life cycle assessment of lithium-ion batteries for plug-in hybrid electric vehicles - critical issues. J Clean Prod 18(15):1519-1529 